\title{
LANGUAGE IN MILITARY SERVICE
}

\author{
Brig (Dr) J.H. Picard, SM*
}

\begin{abstract}
Vanaf sy stigting in 1912 tot vandag het doeltreffende taalgebruik in beide amptelike voertale 'n hoofrol gespeel en die rol is selfs verskans in die bepalings van Artikel 137 van die Verdedigingswet 1957 , soos gewysig. Hiervolgens is gelykberegtiging van die beide amptelike voertale die SAW se beleid. Die voertale in bevele, instruksies, opleiding en korrespondensie word maandeliks gewissel en alle opleidingstof en amptelike stukke word in beide tale opgestel. Die Krygstaalraad, wat ' $n$ hoofrol gespeel het in die skepping en bevordering van Afrikaanse Krygsterminologie, het in 1954 die Weermagswoordeboek die lig laat sien en so word die SA Weermag die leier op die gebied van die Afrikaanse krygsterminologie. Hierdie leierskap is gehandhaaf en bestendig met die stigting van 'n Militêre Taaldiens in 1968.
\end{abstract}

Oor die jare het die diens ontwikkel in die grooste taaldiens van sy soort in die land. Die diens gee spesifiek aandag aan die verbetering van Engelse en Afrikaanse taalgebruik, die opstel van talle woordeboeke, die onderrig in die twee landstale, in vreemde tale en ook moedertaalonderrig en toetsing in die Afrikatale.

Why is language important to the military?

We may as well ask: "Why is language important at all?" and "How do we communicate?" For communication in the world of mankind takes place by way of one medium: Language; although language may be reinforced by symbols, signs and body language. Poor communication implies poor leadership and management and the latter in the military will ensure defeat, thus thwarting a chief military goal: To win the war. But communication also plays a cardinal role in three other major goals: to maintain a high morale, to establish a positive external image for a defence force and to manage the defence force efficiently.

People think in the language they learn, they solve their problems in that medium, they internalise and learn experiences in that medium and they formulate, utter and convey to others that wich they have learnt, by way of opinions, advice, requests, instructions or commands.

Good language communication - i.e. timeous, unambiguous, succinct and intelligible language signs embodied in correct grammar, vocabulary, spelling, diction and context - serves to train and instruct personnel and enhances their understanding of the organisation's goals and interests. It also clearly shows personnel how they may link their own goals to those of the organisation in order to obtain the greatest personal satisfaction in optimally promoting the organisation's goals - an essential morale-builder.
Clear, correct and pro-active language communication to the outside, clearly understood by the public, leading to a sound and constructive two-way dialogue will certainly immeasurably reinforce the positive image of a defence force and get the public on its side. And it is indisputably true that a defence force needs the support of all elements of the population to win the war.

As important is the efficient management of a defence force. There are many ways to do this: Orders, directives, commands and instructions both verbal and in writing must be unambiguous, timeous, concise and yet complete so that the reactions and actions of the addressees will promote the goals of the organisation. In the SA Defence Force we also use tools such as the Conventions of Service Writing, clearly described and defined procedures, clear meeting procedures and, of course, an acceptable measure of language proficiency on the side of the personnel. The latter aspect is perpetuated by way of sound language tuition and language proficiency testing, for how can you properly execute a command if you do not understand it or its implications?

In essence, therefore, language is vital to mankind in general, and forms a cardinal structure for implementing the goals underlying the raison d'être of a defence force in particular.

The question arises: How does the SA Defence Force employ this vital tool? 


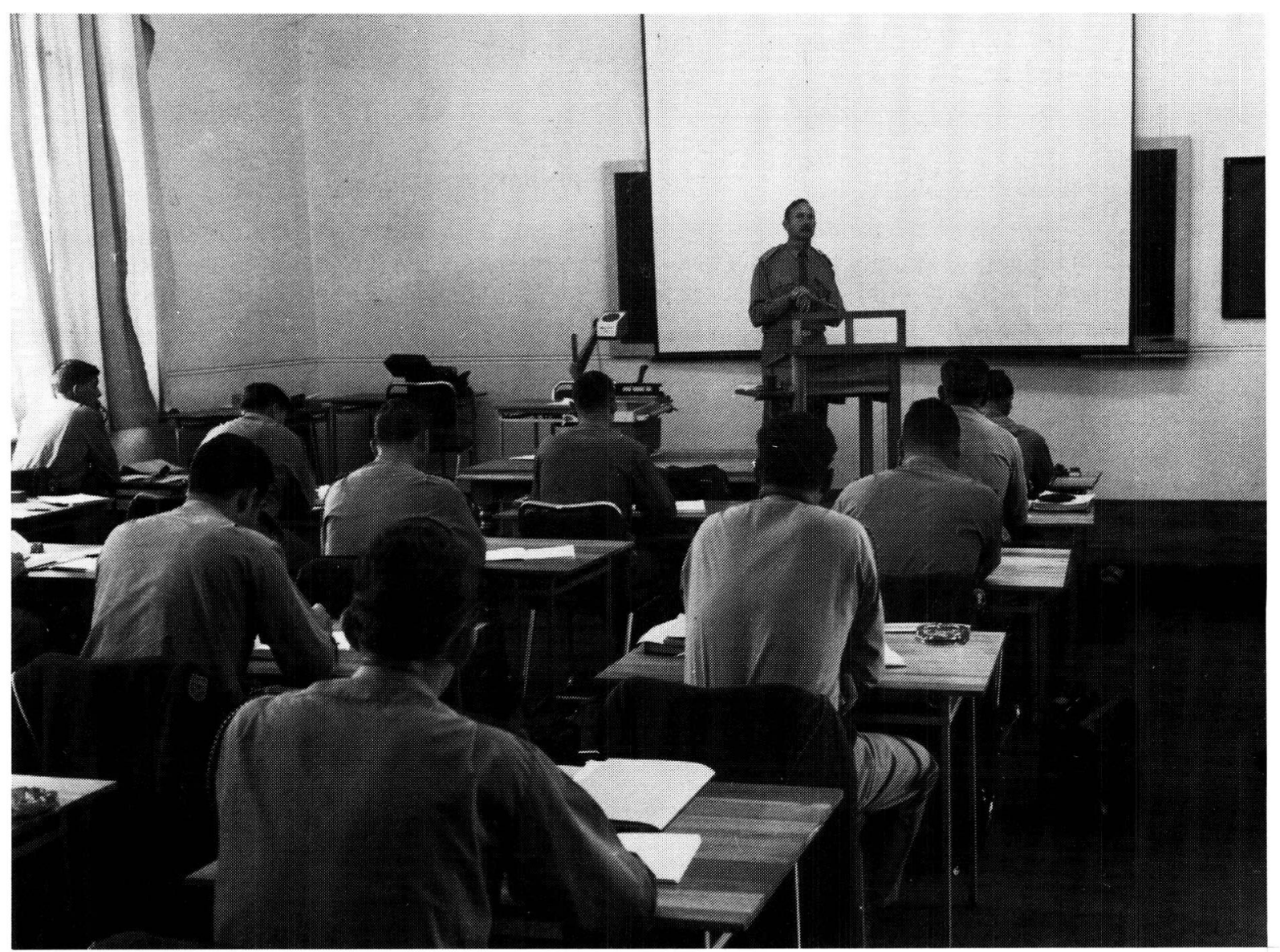

Although language training often takes place in the field or under operational conditions, classroom tuition, as in other non-language courses, remains essential.

From its establishment in 1912 to the present, in its seventy six years of existence, effective language use in both official languages, Afrikaans and English, has always played a main role. Indeed, it is incorporated in the provisions of Section 137 of the Defence Act, 1957 as amended. Certainly, orders, commands and instructions are conveyed by means of the spoken and written word. In terms of its language policy the SADF alternates the official language used in correspondence monthly, and lectures at its training establishments are presented alternately in English and Afrikaans. Hence the SADF may rightly claim the highest possible measure of bilingualism.

Initially, language stood in the political forefront. Hence, Afrikaans was strongly promoted after its promulgation as official language in Transvaal in 1925. Like many other organisations the Union Defence Force, later to develop into the SA Defence Force, made a great contribution to the promotion and sophistication of this young and vital new language. Translators such as Crafford and Posthumus started coining, recording and standardising Afrikaans military terms and in
1949 the first Afrikaans-English Military Dictionary appeared, followed by the SA Defence Force Dictionary in 1954, the product of the Military Language Board (Krygstaalraad).

During World War II the men in the forces continued the development of the two official languages. For English and Afrikaans-speaking soldiers served together and shared hardships, defeats and the final victory. The English-speaking serviceman learnt Afrikaans and the Afrikaansspeaking serviceman improved his English. In this way the bonds between the two language groups were strengthened.

Many new military terms were taken from the Dutch, particularly naval and artillery terms. But the English world language made considerable contributions. Often it was necessary to create words and terms reflecting typical South African conditions: Sonfontein (solar still), pantserbreekgranate (armour-piercing squash head shells), steunkring (defended locality), verneukmyn (booby trap), loopgeselser (walky talky). So the Defence Force became the leader in the field of Afrikaans arms' terminology. 


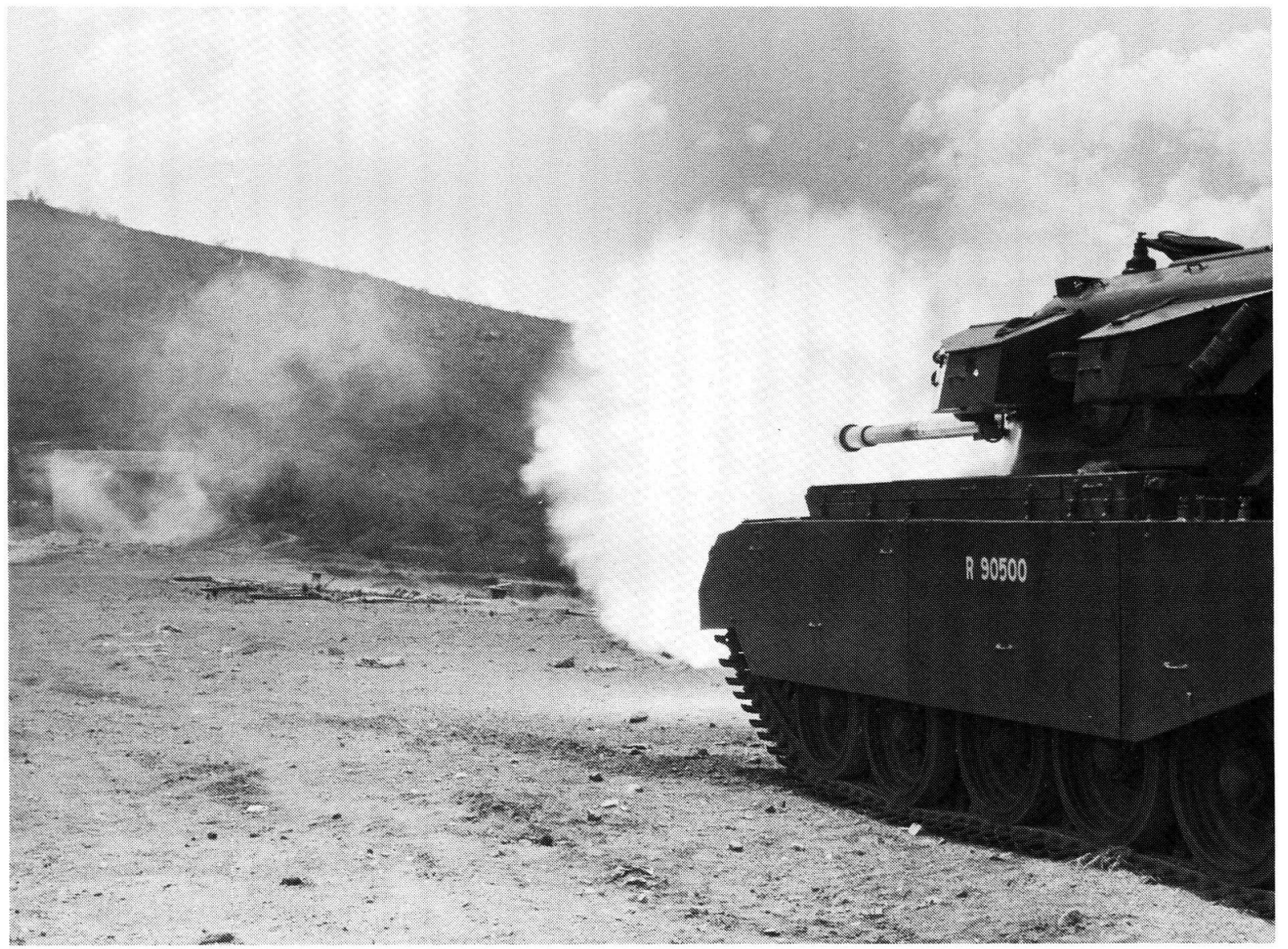

When a tank engages a target, many language communication processes precede the final command "Fire", from interpretation of the situation, solving the problem posed, to executing the task by firing at the target.

This leadership is maintained and perpetuated by the establishment of a Military Language Service in 1968. And over the years this language service expanded and developed into the largest such service in the country because the needs of the SA Defence Force in the field of language communication are so great. Official documents are translated, manuals, directives, speeches, press releases are issued in both official languages, language guides are compiled and distributed, thousands of members receive language instruction, immigrants learn Afrikaans and English, Black members learn the official languages, White members learn African languages and many members of the Defence Force learn languages such as French, German, Spanish, Portuguese, Hebrew, etc. In addition, the SADF Language Service liaises with all language bodies and authorities in an effort to improve the quality of language communication for the quality and effectiveness of the training, battle handling, liaison and intelligence depends largely on the effectiveness of our language usage. And obviously liaison with our multiracial population is done best by medium of their own languages. So the SA Defence Force helps to build up goodwill amongst languages and amongst population groups.

The Language Service of the SA Defence Force is a directorate headed by a brigadier and it comprises 3 sections, each led by a deputy-director or colonel: language Teaching and Testing, Terminology and Translation Services.

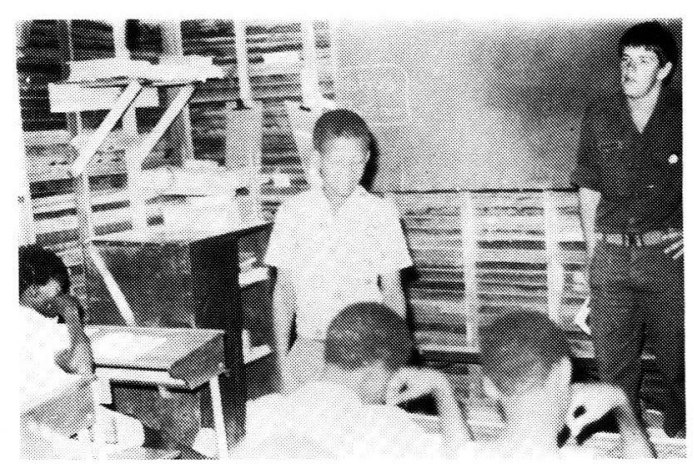

Teaching Afrikaans and English to members of local populations is an important cultural contribution by the SADF. 


\section{Language Teaching and Testing}

The language teaching section develops courses in most modern languages and offers courses in all those languages to members of the Defence family and selected staff from other Government Departments. The latest audiovisual methods are employed and the courses are purpose-designed, i.e. for the particular subject field or activity the student is involved in. Mother tongue tuition is emphasized throughout. This is particulary important in the SADF effort to teach all its members in constant daily contact with other population groups the necessary African Languages. In 1987 close on 1200 members were taught: Zulu, Xhosa, Tswana, North Sotho, South Sotho, Venda, Tsonga, Seswati and other languages. In the effort Black SADF instructors are used. In respect of language testing, a unique new set of tests to test the proficiency of SADF members in the written and spoken languages has been developed and is to be implemented this year.

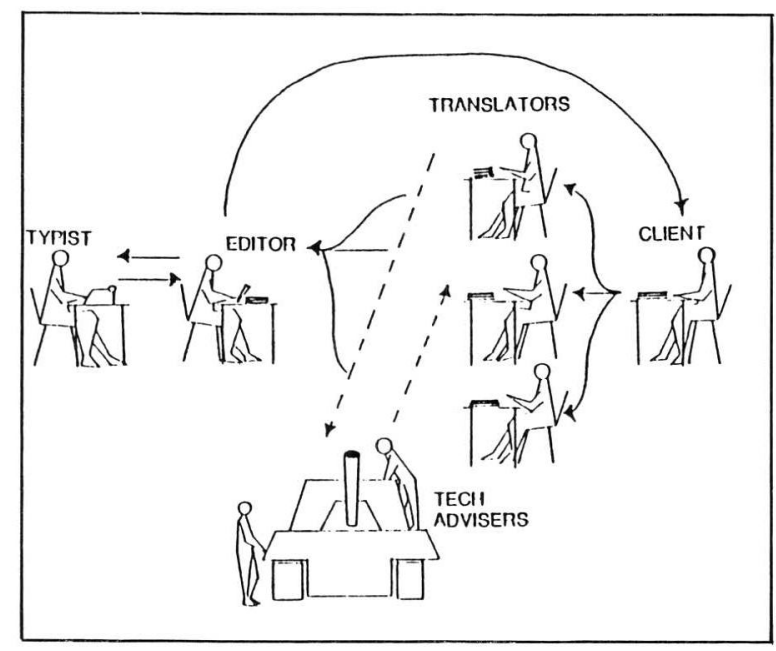

The translation process in outline.

\section{Translation Services}

The translator in the SADF not only translates but he also edits and corrects written work in the official languages. In addition, most foreign and African language translations are done on a daily basis and interpreting services, such as during the NKomati Accord and the International Aeromedical Congress are offered.

\section{Terminology Services}

The SA Defence Force Language Service is the pioneer in South Africa in the field of computerised terminological and lexicography services. Its publications including the Joint Military Dictionary, Personnel Management Dictionary, Artillery Dictionary, Naval Dictionary, Ammunition Dictionary, Weapons Dictionary, Glossary of Tactical and Strategic Terms, Financial Dictionary etc. are compiled by way of computer, thus saving cost and manpower and facilitating more rapid producion.

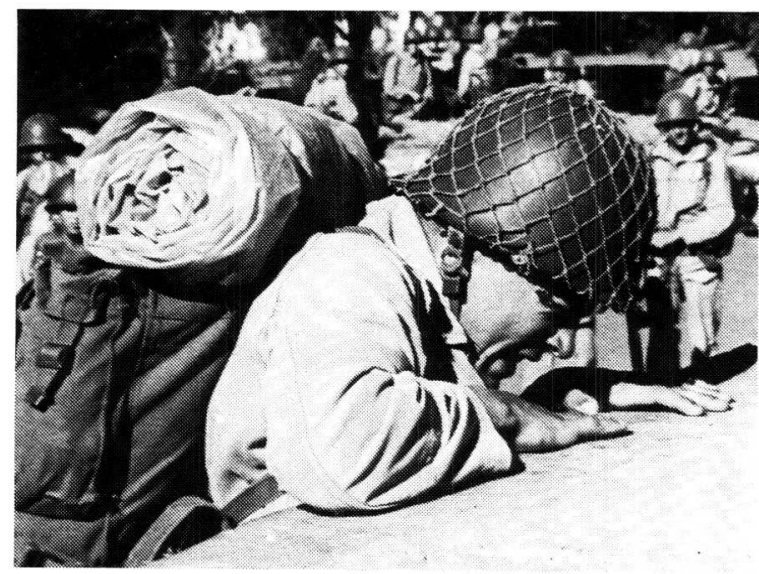

He and his buddies have a hard time ahead but they will probably become life-long friends and communicate in one another's languages.

In addition to these tasks, the Language Service has been involved in compiling and presenting literacy courses, undertaking sociolinguistic research and recording and updating language data. The Service is responsible for the publication of language guides and it edits and publishes the Conventions for Service Writing/Die Reëls vir Militêre Skryfwyse.

The SA Defence Force is indeed doing its utmost to improve the quality of its communication in all the relative languages and in the process building bridges across cultures and languages in the interest of better relations amongst South Africa's heterogenous population groups.

\footnotetext{
* Brig (Dr) J.H. Picard, S.M is Director of the SADF Language Service.
} 


\section{PROFESSIONAL CODE: BEROEPSKODE}

As professional language officer you shall be guided by two principles:

a. As member of the corps of officers of the SA Defence Force you shall serve your country with loyalty, courage, dignity and honour and discharge your duties and responsibilities with zeal and diligence, setting a good example to those placed under your control.

b. As member of the corps of professional language officers you are bound to execute all work according to the highest standards of the profession, taking every reasonable precaution and observing the strictest security.

As professionele taaloffisier moet twee beginsels u lei:

a. As lid van die offisierskorps van die SA Weermag moet $u$ u land met trou, moed, waardigheid en eer dien, u pligte en verantwoordelikhede met nougesetheid en ywer nakom en diegene wat onder $u$ gestel is, met 'n goeie voorbeeld voorgaan.

b. As lid van die korps van professionele taaloffisiere verbind $u$ uself om alle werk volgens die hoogste standaarde van die beroep uit te voer, alle redelike voorsorg te tref en die strengste sekerheid te handhaaf. 